DAKWATUNA

Jurnal Dakwah dan Komunikasi Islam

Volume 6, Nomor 2, Agustus 2020

p-ISSN: 2443-0617

e-ISSN: 2686-1100

\title{
Dakwah Mengenai Hak Asasi Manusia (HAM) Di Indonesia Dalam Konsep Maslahah Mursalah
}

\author{
Rojabi Azharghany \\ Universitas Nurul Jadid Probolinggo, Indonesia \\ Email: azharghany@gmail.com
}

\begin{abstract}
Da'wah regarding Islamic values needs to be done in the community. Including, preaching about the Islamic values contained in the views that are being discussed in the public sphere, including about Human Rights (HAM). Democratic governance requires the existence of good governance, human rights and democracy. Obtaining the standards of democratic governance is needed by Indonesia to be internationally accepted. Nonetheless, Indonesia's record on human rights leads to the understanding that this country has to pay highly attention on human rights. Five basic rights in maqashid sharia (kulliyatul khoms) as important basic ideas to be elaborated into values that are included in the effort to realize good governance.
\end{abstract}

Keywords: Da'wah, good governance, human rights, kulliyatul khoms

\begin{abstract}
Abstrak
Dakwah mengenai nilai-nilai keislaman perlu dilakukan di masyarakat. Termasuk, berdakwah mengenai nilai keislaman apa yang terkandung dalam pandangan-pandangan yang sedang diperbincangkan di ruang publik, antara lain tentang Hak Asasi Manusia (HAM). Pemerintahan yang demokratis mensyaratkan adanya tata pemerintahan yang baik (good governance), hak asasi manusia dan demokrasi. Indonesia butuh mewujudkan standar pemerintahan yang demokratis supaya diterima kalangan internasional. Namun, catatan Indonesia pada persoalan HAM mengarah pada pemahaman bahwa negara ini harus mencurahkan perhatian dengan keras pada persoalan HAM. Lima hak dasar dalam moqosid asyariah (kulliyatul khoms) sebagai ide dasar yang penting untuk dielaborasi menjadi nilai-nilai yang menyertai upaya mewujudkan pemerintahan yang baik.
\end{abstract}

Kata Kunci: Dakwah, good governance, hak asasi manusia, kulliyatul khoms

\section{PENDAHULUAN}

Dakwah adalah aktifitas menyeru atau mengajak manusia ke jalan ajaran Islam dengan cara yang bijaksana, menyebarkan nasehat, dan berdiskusi atau 
berdebat dengan cara yang baik1. Dakwah umumnya bertujuan untuk melakukan perubahan wawasan atau pengetahuan dari sasaran dakwah sesuai dengan ajaran agama Islam. ${ }^{2}$ Dakwah perlu tetap memberikan atensi pada aspek interaksi dan aspek kultural atau kondisi masyarakat setempat³.

Di era kekinian, dakwah bisa dilakukan melalui berbagai media dan menyentuh beragam topik. Media maupun topik itu tentu saja, yang dianggap sedang menjadi sudut pandang dari kehidupan masyarakat ${ }^{4}$. Yang terpenting, aktifitas dakwah mesti tetap bersandar pada nilai-nilai Al-Qur'an dan Sunnah Nabi Muhammad 5 . Salah satu topik yang banyak diperbincangkan dengan menghubungkan perspektif Islam, adalah tentang Hak Asasi Manusia (HAM). Oleh karena itu, mengajak manusia berpikir dengan cara yang baik mengenai HAM, sehingga bisa bersikap yang baik pula dalam menghadapinya, adalah sebuah keniscayaan.

Definisi klasik dan menggejala dalam pemaknaan HAM yang sering dipakai dan dikutip adalah:

A human right by definition is a universal moral right, something which all men, everywhere, at all times ought to have, something of which no one may deprived without a grave affront to justice, something which is owing to every human being simply because he [she] is human (Cranston, 1973:36).

Dari definisi di atas dan sejumlah definisi lain yang diberikan dalam mencermati HAM, pemahaman atas HAM selanlutnya disebut sebagai

\footnotetext{
${ }^{1}$ Ropingi El Ishaq, Pengantar Ilmu Dakwah (Studi Komprehensif Dakwah dari Teori ke Praktek) (Malang: Madani, 2016), 11.

${ }^{2}$ Anggit Rizkianto, Manajemen Strategi Organisasi Dakwah (Studi pada Pimpinan Daerah 'Aisyiyah Surabaya) (Tesis, UINSA Surabaya, 2018), 1.

3 Rio Febriannur Rachman. (2018). Dakwah Intraktif Kultural Emha Ainun Nadjib. Jurnal Spektrum Komunikasi, 6(2), 1-9.

${ }^{4}$ Abdul Ghofur. (2019). Dakwah Islam Di Era Milenial. Dakwatuna: Jurnal Dakwah dan Komunikasi Islam, 5(2), 136-149.

5 Faiqotul Mala. (2020). Mengkaji Tradisi Nabi Sebagai Paradigma Dakwah Yang Ramah. Dakwatuna: Jurnal Dakwah dan Komunikasi Islam, 6(01), 104-127.
} 
berkarakter universal (untuk semua orang, waktu dan tempat), dimiliki oleh semua manusia (chan, 1995:58) dan harus dilakukan oleh semua manusia (Prajarto, 2003: 377). Dari sisi karakter ini saja sejumlah persoalan dan gugatan atas HAM kemudian mengemuka. Pertama tentang makna dan aplikasi universalitas HAM. Kedua, benarkah itu dapat dimiliki dan dilakukan oleh semua orang jika suatu sistem politik tidak memberi ruang gerak yang memadai?

Sejumlah studi dan kajian yang dilakukan pemerhati hak asasi manusia mengantar pada sejumlah penyebab munculnya gugatan atas ide dan nilai universal HAM. Bila disebutkan, gugatan umum terhadap universalitas HAM adalah sebagai berikut:

(1) Nilai universal HAM berakar dari pemikiran filosofi dan filosof Barat (western bias) dan dari keyakinan kalau semua orang berpikir dalam corak yang seragam (Renteln, 1990: 47-50).

(2) Beberapa hak yang termuat di dalam Human- Rights pada dasamya tidak memenuhi persyaratan untuk "all times" (Chan, 1995: 29). Sebagai contoh, hak untuk memilih wakil rakyat dan hak untuk menikah yang te_ntunya tidak mungkin iiberlakukan pada semua umur. Atas dasar ini maka karakter universal dipandang tidak memenuhi Persyaratan lagi.

(3) Beberapa hak yang terefleksikan dalam hak asasi manusia cenderung berakar pada ideologi dan budaya liberal dengan mengabulkun nilainilai komunitarian yang kemungkinan dipunyai oleh suatu negara dan masyarakat tertentu. Dengan kata lain, suatu negara atau masyarakat tertentu pada dasamya memiliki aturan sendiri dalam melindungi dan mengakui hak anggotanya.

(4) sejumlah negara Asia termasuk Indonesia memandang universalitas HAM sebagai bentuk agresivitas, imperialisme kultural, hegemoni 
global, dan pendiktean Barat atas negara berkembang. (Ghai, 1995;56; dan Caballero-Anthony, 1995: 40).

Meskipun muncul sejumlah gugatan sebagaimana di atas, Freeman (1995:17) memiliki pandangan bahwa HAM hanya secara kesejarahan saja berasal dari Barat, namun tetap berkarakter universal dan internasional: "legally international, philosophically universal and historically Western" .

Terlepas dari kecurigaan-kecurigaan dan pemikiran semacam itu, hampir semua negara, termasuk Indonesia, untuk tetap bersedia menerima universalitas HAM (Bhimo and wid adi, 1999: 775). Dalam Deklarasi Bangkok (29 Maret - 2 April 1993) sebelum the world Conference on Human Right di Wina antara 14 dan 25 Juni 1993, sebagai contoh, tersirat penerimaan HAM universal ini meskipun Indonesia tetap berharap tetap ada perhatian terhadap beda latar belakang spesifik (sejarah dan budaya, misalnya). Bila kenyataan yang terjadi pada tahun 1993 itu ditarik ditarik ke masa sekarang, tentu dapat dipertanyakan lebih jauh apakah penerimaan terhadap ide dan nilai universal ini muncul karena penerimaan yang hakiki atas makna universal atau sekadar untuk memenuhi persyaratan standar dalam hubungan antarnegara.

Patut dicatat bahwa sejumlah negara, Australia sebagai contoh, memberi persyaratan tentang jaminan HAM yang maksimal untuk menjalin hubungan bilateral dan multilateral. Selain itu ada pula kemungkinan bahwa penerimaan HAM universal dipengaruhi oleh tuntutan democratic goaernance.

Sejumlah negara juga melangkah jauh dalam mencapai standar internasional HAM, yang di antaranya dilakukan dengan mendirikan Komisi Nasional untuk HAM. Terlepas dari segala motivasi dan latar belakang pendiriannya, Komisi Nasional HAM di sejumlah negara Asia dan Pasifik kebanyakan didirikan atas saran Perserikatan Bangsa-Bangsa (United Nations) dengan bantuan dari negara-negara yang dipandang cukup maju implementasi HAM-nya. Hanya saja, sekali lagi dapat dipertanyakan dasar penentuan suatu negara, seperti Australia, sebagai suatu negara yang memiliki catatan bagus 
tentang HAM karena dalam kenyataannya Pun Australia masih menghadapi sejumlah perrnasalahan HAM. Selain pendirian Komisi Nasional HAM, sejumlah negara kemudian menetapkan Action Plan, yang sekali lagi merupakan hasil fotokopi dari program Action Plan yang dilakukan negara-negara tertentu.

Namun persoalan tidak berhenti pada penerimaan universalitas serta uPaya-uPaya Pencapaian standar internasional HAM. Untuk kasus Indonesia, definisi Cranston di depan barangkali perlu dilengkapi dan dipertajam. Beberapa kejadian pelanggaran HAM di Indonesia menunjukkan perlunya pemahaman HAM tidak sebatas karena hak itu dipunyai oleh semua manusia, namun juga pelayanan terhadap hak itu perlu dilakukan oleh semua manusia. Pada tingkatan lain, apresiasi terhadap HAM di Indonesia perlu pula dipertajam agar tidak sekadar terfokus pada masalah-masalah HAM besar seperti pembunuhan, perusakan massal dan genocide. Nilai-nilai HAM seharusnya diterapkan secara menyeluruh di segala lapisan masyarakat sehingga segala bentuk diskriminasi rasial, seksual dan abilitas benar-benar mendapat perhatian yang memadai. Di sisi yang lain, pandangan awam yang terlalu menyederhanakan HAM perlu pula diluruskan.

Bila dikaji lebih dalam, rentetan persoalan HAM di Indonesia tidak sekadar bermuara pada terjadinya pelanggaran HAM dan upaya penyelesaiannya. Alasannya adalah bila hanya hal itu saja yang dijadikan alat ukur, maka persoalan HAM hanya akan diukur secara kuantitatif antara kasus HAM yang terjadi dan jumlah kasus yang diselesaikan. Perbaikan dan penguatan civil society, penegakan hukum, re-Proporsi kekuasaan dan wewenang, pendidikan dan sosialisasi HAM tidak sertamerta menjadikan Indonesia tampil dengan persoalan HAM yang minimal (Department of Foreign Affairs and Trade, 1998: iii; dan Bell, 1996:42). Hal itu juga tidak kemudian memudahkan Indonesia dalam berurusan dengan lembaga atau negara donor, apalagi mencaPai democratic governance. Dengan kata lain persoalan HAM di Indonesia pada dasarnya telah berhulu dan berhilir pada tata penyelenggaraan 
pemerintahan yang dilakukan. Pemerintah di setiap level, mulai di level pusat, provinsi hingga kabupaten/kota, memiliki tanggungjawab mengawal ekonomi rakyat $^{6}$, pembangunan sosial melalui industri kreatif ${ }^{7}$, pendidikan ${ }^{8}$, dan hal-hal elementer lainnya. Meski demikian, tetap pula menaruh perhatian ekstra pada HAM.

Persoalan-persoalan mendasar HAM di Indonesian di antaranya dapat dilihat dari hal-hal berikut ini.

\section{Landasan Solid HAM}

Harus diakui bahwa penegakan dan perlindungan HAM di Indonesia masih tetap membutuhkan landasan yang baku dan kuat. Perubahan pemakaian Konstitusi di Indonesia sejak masa kemerdekaan menunjukkan fluktuasi jaminan HAM di Indonesia. Amandemen terhadap UUD 1945 barangkali bisa mengarah pada perbaikan jaminan HAM, namun ahli hukum pada umumnya melihat bahwa UUD 1949 dan UUDS 1950 lebih mengakomodasi jaminan HAM. Dengan kata lain, sejumlah konstitusi yang pernah diterapkan di Indonesia menunjukkan adanya sikap maju-mundur terhadap penegakan dan perlindungan HAM. Dalam hal ini Lubis (1993) menengarai UUD 1945 hanya memuat beberapa Pasal terkait dengan HAM, UUD 1949 cenderung mengadopsi dan menerima universalitas HAM, UUDS 1950 memperluas cakupan HAM,'dan penggunaan kembali UUD 1945 sejak Dekrit Presiden 5 juli 1959 sebagai langkah mundur dalam penegakan HAM di Indonesia.

Dari kajian historis, kebanggaan terhadap munculnya pemikiran dan peneraPan HAM bisa dilacak dari hal-hai yang dilakukan rakyat dan tokoh-

\footnotetext{
${ }^{6}$ Rio Febriannur Rachman. (2019). Optimalisasi Media Digital Berbasis Kemaslahatan Umat dalam Program Pahlawan Ekonomi Surabaya. IQTISHODUNA: Jurnal Ekonomi Islam, 8, 273-292.

7 Rio Febriannur Rachman. (2019). Pengembangan Industri Kreatif Berbasis Media Digital di Surabaya dalam Perspektif Islam. KOMUNITAS, 10(2), 157-176.

${ }^{8}$ Rio Febriannur Rachman. (2020). Kebijakan Pendidikan Anak Berkebutuhan Khusus Di Surabaya Dalam Perspektif Islam. Bidayatuna: Jurnal Pendidikan Guru Mandrasah Ibtidaiyah, 3(01), 125-143.
} 
tokoh nasional dengan pepe (berjamur di depan Keraton), perjuangan Pangeran Diponegoro di yogyakarta dan Tjoet Nja' Dien di Aceh (menentang kolonialisme), korespondensi Kartini (persamaan derajad antara laki-laki dan perempuan serta hak mendapat pendidikan), hingga ke masa yang relatif lebih bersifat kekinian seperti pendirian Komisi Nasional HAM (Komnas HAM), ratifikasi sejumlah kovenan yang sebelumnya tidak dilakukan, dan penerapan proses hukum bagi pelanggar (schwarz, 1999: 4; Cribb dan Bro wn, 1995: 1-12; dan Leirissa, 1985: 61-77).

Persoalan perbaikan dan perlindungan HAM yang lain di Indonesia muncul dari kontroversi penerapan uu tentang HAM, gugatan terhadap eksistensi Komisi Nasionat HAM serta penerapan hukum bagi pelanggar HAM yang banyak dipertanyakan masyarakat. Sebagai contoh, eksistensi Komisi Nasional HAM mendapat kritikan karena dibentuk oleh Pemerintah yang sedang berkuasa (dipandang sebagai lips-service untuk kalangan internasional), dikhawatirkan hanya sebagai toothless-tiger karena tidak mampu menjangkau pelanggar-pelanggar HAM dari kalangan tertentu penerapan hukum, contoh lainnya, menimbulkan sejumlah tanda tanya bagi kalangan di dalam dan di luar negeri. Hasil proses peradilan pelanggaran HAM di Timor-Timur mendapat tanggapan bernada kecewa dari Komisi HAM Perserikatan Bangsa-Bangsa. Tidak atau belum tuntasnya sejumlah kasus HAM (kasus Tanjung priok, Lampung, DoM di Aceb konflik sosial-agama di Maluku, terbunuhnya wartawan Bernas Syafruddin (Udin) di Yogyakarta, Peristiwa penyerbuan kantor Partai Demokrasi Indonesia "sabtu Kelabu 27 luli", tewasnya aktivis buruh Marsinah, penembakan semanggi penghancuran massal Timor Timur, penembakan di Papua, tewasnya Munir, dan bahkan kasus kudeta tahun 1965 yang kembali berusaha diungkap) mengindikasikan adanya persoalan soliditas landasan penegakan HAM di Indonesia. 
Pada gilirannya, kurang memadainya landasan kuat untuk jaminan HAM memunculkan kekhawatiran tentang ragam pelanggaran HAM yang secara potensial akan tetap muncul, meskipun tidak ada jaminan juga bahwa landasan yang solid untuk penegakan HAM akan meniadakan pelanggaran. Pernyataan ini tentunya senada dengan pernyataan Amnesty Internasional (1994 dan 1998) yang menyatakan bahwa tidak ada satu negara pun yang terbebas dari persoalan dan pelanggaran HAM. Namun demikian, klaim yang sesungguhnya lebih tepat disebut sebagai kritikan Amnesty Internasional ini tentu tidak boleh menciptakan kondisi pemakluman adanya pelanggaran HAM. Kesadaran kurang memadainya jaminan HAM dalam Konstitusi Indonesia perlu ditindaklanjuti dengan perbaikan demi perbaikan atau amandemen demi amandemen jika tetap UUD 1945 yang dipakai sebagai dasar.

\section{Kebijakan Antar Rezim}

Semangat untuk "memanjakan" HAM biasanya hanya berlangsung pada tahun-tahun awal pergantian atau dimulainya suatu rezim. Dua tahun pertama suatu pemerintahan baru di Indonesia biasanya memang memberi janji politik positif terhadap jaminan dan perlindungan HAM. Sebagian bahkan menyebut bahwa masa dua tahun itu slbagai waktu bagi euphoria masyarakat untuk mendapatkan jaminan HAM-nya sebigai warganegara. Namun demikian, penyimpangan-penyimPangan terhadap pemberian perlindungan HAM cenderung terjadi setelah itu karena berbagai alasan. Dari kacamata negara, pembatasan HAM tentu disebutkannya sebagai uPaya untuk menjamin kesatuan dan persatuan bangsa serta keamanan dan ketertiban masyarakat. Dari kacamata yang lain, pembatasan dan bahkan pelanggaran HAM tetap saja tercatat sebagai suatu aib bagi rezim yang berkuasa dan melakukannya.

Pemusatan kekuasaan selain alasan-alasan di atas, layak disebut sebagai sumber dari persoalan-persoalan HAM yang ada di Indonesia. 
Dekrit Presiden 5 luli 1,959 dan Dekrit Anti-Subversi No. 11/1963, pelarangan dua partai politik dan pembungkaman Harian Rakjat yang terjadi pada jaman Soekarno dapat dipandang sebagai cermin pelanggaran HAM karena kebutuhan untuk melakukan pemusatan kekuasaan. Dalam beberapa kasus mungkin tidak terlihat langsung adanya hubungan antara pemusatan kekuasaan dan tindakan represif pemerintah. Meskipun demikian bila dicermati lebih dalam, tindakan represif itu tidak dapat dilepaskan dari keinginan Pemerintah untuk "tidak terganggu" (Samad, 1999: 773, Crouch, 1988: 346; Southwood dan Flan agary 1983: 742-146;Jenkins, 1984:6-12;dan Bhimo dan Widadi, 1999: 767-170).

Pengingkaran HAM yang teriadi pada masa kekuasaan rezim orde Baru juga menampakkan kecenderungan yang serupa. Dalam kurun waktu 32 tahun, sejumlah kebebasut 6erserikit dan kebebasan Pers dicederai, diganggu dan bahkan dimatikan. Selain itu, interpretasi terhadap Pancasila (melalui dan dengan nama Demokrasi Pancasila, Pers Pancasila dan Ekonomi Pancasila) cenderung ditentukan oleh kekuasaan dan besifat terpusat (cribb dan Browru 1995: 145; schwarz,1999: 24-39 dan 319; dan Aspinall, 1998: 131-132). Dalam periode orde Baru ini, Lubis (1993: 756-289) mencatat adanya sembilan dilema hukum yang mengganggu penghormatan terhadap HAM di Indonesia. Kesembilan dilema itu dikategorikannya sebagai politics of regulation, the democracy Pancasila, the dual function of $A B R I$ (dwi fungsi $A B R I)$, the gradual cooptation, "insiders or outsiders?", effective portiripation, partial participation or pseudo participation, the press Pancasila, from SIT to SIUPP dan censorship. Dengan klasifikasi atau kategorisasi yang lain mungkin dapat teridentifikasi juga persoalan HAM yang ada di Indonesia selama jaman Orde Baru.

Tiga jenis pelanggaran mengemuka dan layak catat selama periode pemerintahan Presiden Soekarno dan Soeharto (Orde Baru). Ketiga jenis pelanggaran itu adalah pembatasan hak berserikat, pembungkaman Pers, 
dan terbuluhnya pelajar atau mahasiswa. Hal terakhir ini pada umumnya terjadi pada tahun-tahun akhir masa pemerintahan mereka, walaupun kenyataan itu tidak berarti bahwa Soekarno atau Soehartolah yang secara langsung memberi instruksi dan bertanggung jawab untuk hal itu. Sedangkan dua pelanggaran pertama sekali lagi menegaskan bahwa pemusatan kekuasaan merupakan latar belakang terjadinnya aksi-aksi represif itu.

Hal lain yang dipandang ikut mempengaruhi kebijakan Soekarnodan soeharto terkait dengan masalah pelanggaran HAM adalah keterlibatan ABRIITNI di kawasan politik (samad" 1999:113; schwarz, 1999: 75-16; dan Croucb 1988: 24). wilayah sosial dan politik (bahkan ada yang menambahnya dengan'bisnis' sehingga tidak sekedar menjadi dwi fungsi melainkan tri fungsi) dipandang memperlebar peluang militer untuk masuk ke ranah pembuatan kebijakan-kebijakan, pelaksanaan dan pengawasannya, hingga justru mendominasi politik di Indonesia. Sejalan dengan runtuhnya rezim Orde Baru, patut dicatat semangat reorientasi militer di Indonesia (TNI/Polri) yang menetapkan paradigma baru "yang terbaik bagi rakyat, itulah yang terbaik bagi TNI".

Namun demikian, terlepas dari pro dan kontra serta segala kritik yang diberikan, satu hal paling positif dalam usaha penegakan dan perlindungan HAM yang yang terjadi pada masa pemerintahan soeharto adalah terbentuknya Komisi Nasional HAM (Human Rights and Equal Opportunity Commission, 1997 :8-9). Lembaga ini dalam.kenyataannya menjadi tempat aduan pelanggaran HAM yang tidak sekadar menampung, namun juga membantu penyelesaiannya, melakukan penelitian untuk mencari kebenaran serta memberi rekomendasi kepada pihak tertentu untuk melakukan langkah-langkah yang dipandang tepat untuk memPerbaiki jaminan HAM di Indonesia. 
Kecenderungan situasi bisa jadi mulai dan telah berubah pada jaman pemerintahan Habibie, Gus Dur, Megawati Sokarnoputri, susilo Bambang Yudoyono dan sekarang Jokowi. Namun harus dicatat bahwa Periode HAbibi, Gus Dur dan Megarvati Soekamoputri tidaklah selama periode pemerintahan soekarno dan soeharto, sedangkan periode pemerintahan Jokowi masih berjalan dan perlu waktu untuk pembuktian lebih lanjut. Tak dapat diabaikan dan layak dicatat, kebijakan yang dikeluarkan pada masi Pemerintahan Habibie, Gus Dur, megawati dan SBY secara positif memberi angin segar dan kekuatan baru untuk peningkatan dan pertindungan HAM di Indonesia. Situasi positif ini dalam kenyataannya tetap belum berhasil menuntaskan berbagai kasus pelanggaran HAM dan konflik horizontal (sebagai bentuk pelanggaran HAM yang kadang dilepaskan dari perspektif HAM) yang masih saja terjadi. Dengan kata lain pekerjaaan rumah dalam masalah HAM masih banyak yang harus diselesaikan.

\section{Perubahan Aktor Pelanggar HAM}

Pada periode tertentu, beragam pelanggaran HAM yang terjadi, memperoleh liputan dan dipublikasikan media massa, cenderung mendapat perhatian besar dari masyarakat dan, sebagai konsekuensinya kerap menuai kritik di tingkat lokal, nasional dan internasional, biasanya dilakukan oleh kalangan aparatur negara dan militer. Kasus yang terjadi di Nangroe Aceh Darusallam/NAD (pemberlakuan DOM serta konflik bersenjata antara TNI/Polri dan Gerakan Aceh Merdeka atau GAM menurut versi GAM dan Gerakan Separatis Aceh atau GSA dalam versi TNI dan Polri), di Timor Timur (sejumlah tragedi dan perlawanan bersenjata; kini memperoleh kemerdekaannya setelah pelaksanaan jajak pendapat) dan Papua (gerakan separatis Organisasi Papua Merdeka atau OPM yang menginginkan kemerdekaan) dapat dipakai sebagai contoh pernyataan tentang keterlibatan aparatur negara dan militer. 
Tempo. Co melaporkan (kamis, 26 Desember 2013 ) jenis pelanggaran HAM yang menonjol sepanjang 2013. Pelanggaran HAM yang paling mengusik masih didominasi oleh konflik eksploitasi sumber daya alam. Pelanggaran atas kebebasan beragama dan berkeyakinan menyusul di tempat kedua. Terakhir, aparat, mulai dari kepolisian sampai TNI, menyalahgunakan wewenangnya.

Selain pembiaran aparat, kata Haris, Presiden selaku otoritas tertinggi tak pernah berupaya memperkuat komisi pengawas aparat negara, seperti polisi dan TNI. Produk hukum yang dibikin hanya untuk menunjang kepentingan ekonomi-politik kelompok tertentu saja. "Yang dibilang sebagai kejahatan ternyata tak ada sanksinya. Tak heran pelanggaran HAM akan terus berulang," kata Haris.

Meningkatnya pelanggaran HAM sepanjang 2013, kata Haris, karena Presiden Susilo Bambang Yudhoyono melakukan pembiaran. SBY dianggap tak pernah menindak tegas atau minimal meminta institusi pelanggar HAM untuk mengevaluasi diri. "Tak ada komitmen menuntaskan pelanggaran HAM. Cuma janji. Khas SBY."

KontraS menilai, selepas pemerintahan Abdurrahman Wahid, Presiden tak pernah berupaya menyelesaikan persoalan yang menyerempet persoalan politis seperti pelanggaran HAM. SBY, kata Haris, yang sudah memerintah sembilan tahun juga dianggap tak berkomitmen merampungkan kasus pelanggaran HAM. Indikasi makin menguat ketika SBY kian dekat dengan Prabowo Subianto, figur yang dianggap KontraS sebagai pelanggar HAM tapi tetap melenggang bebas.

Namun demikian, kecenderungan menurunnya pelanggaran HAM yang dilakukan militer dan aparatur negara tidak serta merta menurunkan jumlah pelanggaran HAM di Indonesia. Berbagai tindak kekerasan terus berlangsung dan ironisnya ada yang membuat pernyataan kalau terjadinya tindak kekerasan itu dapat dimaklumi. 
Perbedaan pendapat dan perbedaan keyakinan dengan mudah dapat disulut menjadi ajang adu massa, adu kekuatan adu fisik dan tuntutan peniadaan. Artinya jika aparatur negara dan militer berusaha bersikap dewasa dalam masalah HAM, sejumlah individu dan kelompok justru berubah diri dengan "memanjakan" kekerasan, ketidaksantunannyadan ketidakdewasaan berpikir dan sikapnya, dengan mengatasnamakan "keyakinan" .

Arti lebih jauh dari kenyataan baru itu adalah munculnya aktor-aktor pelanggar HAM lainnya sehingga memperpanjang deretan pelanggaran HAM di Indonesia. Angry mobs serta Group dan personal abusers memberi pelangi kategori pelanggar HAM. Sebagai contoh, massa yang menduduki kantor sebuah penerbitan sehingga pekerja media tidak dapat bekerja secara maksimal dan ProPorsional pada dasarnya sama dengan kesalahan aparatur negara pada masa lalu. Pelaku kejahatan yang tertangkap, dipukuli dan kemudian dibakar hidup-hidup, sebagai contoh yang lain, menunjukkan hak asasi untuk kehidupan begitu mudah dirampas oleh orang di luar aparatur negara dan militer. Hal yang terjadi di Indonesia seperti itu nampaknya memberi potret betapa mudahnya hak asasi "dikebumikan" oleh beragam aktor. Sekaligus ini menggarisbawahi pernyataan Bayefski (1997:74-75)yang mensinyalir adanya perubahan aktor pelanggar HAM meskipun alasan pelanggaran sebenarnya tidak mengalami perubahan Secara substansial (baca: terganggu atau terancam kepentingannya).

\section{Fokus Besar Dan Keterlambatan}

Hal umum yang sebenarnya kurang tepat diterapkan adalah bentuk pemahaman dan kesadaran untuk menghormati nilai-nilai HAM di Indonesia yang sering terjebak pada persoalan ukuran atau besaran. Pelanggaran HAM diukur secara kuantitatif atas dasar besaran jumlah korban tingkat kekejian dan cara pelanggaran itu dilakukan serta aktor dan dalang dalam kasus pelanggarein itu. artinya, kasus pelanggaran HAM akan cenderung 
disoroti dan ditangani lebih serius bila jumlah korban, jenis tindak pelanggaran dan aktor pelakunya terkategori berat dan memenuhi kelayakan muat di media massa. Hal ini tentunya juga berkait dengan orientasi dan tolok ukur media dalam memberitakankasus pelanggaran Yang terjadi.

Hal yang seperti digambarkan di atas seakan abai pada persoalan nyata dari nilai-nilai HAM yang teringkari. Persoalan dan pelanggaran kecil sekalipun mestinya tetap dipahami sebagai sebuah persoalan hak asasi manusia di Indonesia. Selain itu, bentuk pelanggaran HAM-nya harus dipandang sebagai suatu kesalahan yang layak dan harus dibenahi. Pengabaian pada pelanggaran hal-hal kecil di sekitar masyarakat biasanya menjadi poison of condition dan tanpa disadari bisa meningkat sedikii demi sedikit. Konsekuensinya, ketika pengabaian menjadi besar, impunity berkecenderungan terjadi. Akibat lainnya, kesadaran atas terjadinya pelanggaraan akan datang terlambat dan rentetan akibat ini semakin panjang saat penanganannya meniadi semakin berat, hingga ke titik "sudah terlalu terlambat".

\section{Topeng Penyelamatan Demi Indonesia}

Persoalan HAM dapat pula berasal dari "kultur" pendewaan negeri yang disadari atau tidak telah terjadi di Indonesia. Kebanggaan pencirian terhadap kekhasan Indonesia seakan membentengi nilai-nilai universal HAM untuk diterapkan. Memang harus diakui bahwa tidak semua nilai bisa diterapkan adalah sebuah keniscayaan, namun berlindung di balik topeng yang bernama "for the sake of Indonesia" pun tidak selalu bisa dan boleh diterapkan. Termasuk dalam hal ini adalah penolakan nilai-nilai HAM hanya karena alasan " demi Indonesia".

Masalah " demi Indonesia" memang layak mendapat pembelaan dan dukungan tentunya hanya bila secara substansial terkait dengan nilai keindonesiaan secara menyeluruh. Namun hal ini menjadi salah bila alasan 
" demi Indonesia" sebenarnya hanya menjadi kedok dari aktivitas sebuah kelompok atau topeng dari kepentingan tertentu yang bila ditelusuri bermuira pada masalah pemusatan kekuasaan dan keengganan untuk menerima kritik dari pihak lain. Dengan kata lain lagi,pencirian Indonesia hanya dipakai untuk menyelamatkan diri bila terbukti melanggar atau tidak memenuhi standar internasional dalam penegakan nilai-nilai hak asasi manusia yang digariskan Perserikatan Bangsa-Bangsa.

Sesungguhnya bila kelima persoalan perlindungan dan penegakun HAM di Indonesia di atas ditautkan, akan dapat mengantar pada sejumlah persoalan mendasar HAM yang kemungkinan juga terjadi di negara-negara lain. Di antaranya adalah persoalan universalism versus particularism dan relativism, permasalahan tentang jaminan konstitusi dan undang-undang, kepincangan antara tataran aturan dan pelaksanaan di lapangan, serta kesulitan-kesulitan dalam rangka mengupayakan keterlibatan Indonesia dalam mencapai standar internasional HAM. Namun di tengah keterengahengahan Indonesia membenahi kondisi HAM yang demikian, hal ini menjadi semakin sulit ketika harus disertai pula dengan langkah lain yang iak jtgu ringan dalam bentuk perwujudan good Governance dan pelaksanaan demokrasi guna mencapai democratic goaernance. Terasa menyesakkan, meskipun tak salah, ketika upaya ke arah itu harus dikaitkan dengan persyaratanuntuk mend apatkan bantuan dan bukan dalam posisi seimbang untuk menunjukkan political stances Indonesia di percaturan internasional.

\section{MENGGERAKKAN HAM, MENUAI MASYARAKAT MADANI}

Bangsa yang beradab selalu hidup dengan menjunjung kemanusiaan. Karena alasan kemanusiaan-lah Tuhan menciptakan manusia. Manusia dilahirkan dengan derajat yang sama, yang membedakan adalah takwanya. Dari takwa itulah letak sumber kekuatan akan hadirnya kekuatan kemanusiaan universal. Sebaik-baik manusia adalah yang bermanfaat bagi manusia lainnya. 
Banyak kejadian yang akhir-akhir ini mengarah pada menguatnya abrasi nilai kemanusiaan dan disintegrasi bangsa. Kenyataan ini tidak luput dari peristiwa-peristiwa chaos seperti intoleransi, menuduh sesat, intimidasi, pembubaran kegiatan keagamaan dan pelanggaran hak dengan mengekploitasi lingkungan.

Kenyataan diatas selain dapat mengarah kepada disintegrasi, juga menjadi catatan buruk bagi keseriusan dalam menangani Hak Asasi Manusia (HAM) di Indonesia. Catatan tentang penegakan HAM di Indonesia mendapat perhatian dari World Justice Project (WJP) yang memberikan perbandingan indeks negara hukum Indonesia dengan sejumlah negara di kawasan Asia Pasifik maupun negara lain di dunia.

Pada akhir tahun 2015, WJP memberikan catatan indikator HAM dalam indeks negara hukum Indonesia amat memburuk. Indeks perlindungan HAM Indonesia berada diperingkat ke-9 dari 15 negara di Asia Pasifik. Indonesia masih tertinggal dari Hongkong, Mongolia, Singapura, dan Thailand. Di tingkat global, Indonesia pada posisi ke 65 dari 99 negara tertinggal dari Guatemala, Sinegal dan Ukraina.

Masyarakat harus sadar bahwa masalah penegakan HAM ini adalah masalah kita bersama. Karena tujuan HAM adalah untuk mewujudkan perdamaian dunia dan kesejahteraan bersama. Sehingga mewujudkan HAM bukan hanya berkepentingan untuk menjaga kemapanan nasionalisme berbangsa tapi juga untuk kepentingan perdamaian dunia.

Konsepsi HAM progresif dan universal tercermin dalam pembukaan UUD 1945 Alenia IV menegaskan bahwa HAM tidak hanya untuk orang Indonesia tetapi untuk umat manusia: "Bahwa sesungguhnya kemerdekaan itu ialah hak segala bangsa dan oleh sebab itu, maka penjajahan di atas dunia harus dihapuskan, karena tidak sesuai dengan perikemanusiaan dan perikeadilan.”

Melihat betapa mulianya tujuan yang dirumuskan dalam pembukaan UUD 1945 dalam kaitan perlindungan hak asasi masyarakatnya, maka sangat 
penting peran masyarakat dalam memahami sekaligus menjadikannya sebagai praktik sosial. Dalam kaitannya dengan ini, pesantren sebagai NU kecil dan NU sebagai pesantren besar adalah bagian dari elemen bangsa yang memiliki peran penting dalam penegakan HAM.

Jumlah pesantren dengan kuantitas hampir mendekati angka 30 ribu yang tersebar di 33 provinsi sangat memungkinkan menjadi motor penggerak bagi penegakan HAM di Indonesia. Apalagi terdapat budaya patron klien bagi masyarakat yang berada disekitar pesantren terhadap institusi pesantren maupun kiai yang berada di pesantren. Hal ini sangat memudahkan bagi berkembangnya dan diterimanya sebuah ide maupun gerakan. Apalagi diperkirakan jumlah pesantren akan terus meningkat.

Nilai-nilai yang menjadi pedoman dan diajarkan di pesantren beserta dengan tradisinya yang selalu dibiasakan kepada masyarakat pesantren, terlahir sebagai nilai dan tradisi yang bernafaskan HAM dan kemanusiaan universal. Kehidupan di dalam pesantren dengan model pendidikan full day, mengajarkan dan membiasakan berbagai macam nilai kepekaan pada kemanusian. Sebut saja misalkan nilai kemandirian, kesederhanaan dan kepedulian bersama.

Selain itu, salah satu dari sekian banyak nilai di dalam pesantren yang menjunjung tinggi prinsip HAM adalah wujud toleransi (tasamuh). Pengembangan dari prinsip tasamuh kiranya bisa dikaitkan dengan konsep yang disampaikan Kiai Ahmad Siddiq tentang persaudaraan. Dalam persaudaraan yang dikembangkan sebagai doktrin pesantren terdapat ukhuwah islamiyah (persaudaraan sesama umat Islam), ukhuwah wathoniyah (persaudaraan sebangsa), dan ukhuwah basyariyah (persaudaraan sesama manusia).

Dengan doktrin dan pengembangan konsep persaudaraan (ukhuwah) ini. Sangat memungkinkan bagi santri untuk menggerakkan sikap dan perjuangan menjunjung tinggi toleransi, sebagai salah satu semangat yang ada dalam Deklarasi Umum Hak Asasi Manusia (DUHAM). Ditambahkan lagi dengan 
prinsip tawasuth (moderat) dan ta'adul (berkeadilan) semakin mengukuhkan bahwa pesantren sebenarnya adalah pembela prinsip HAM yang utama.

Saat ini perlu ada langkah strategis upaya pesantren bukan hanya menggerakkan praktik sosial yang ramah HAM, lebih dari itu menjadikan pesantren sebagai laboratorium tempat lahirnya ilmu sosial yang ramah HAM. Hal ini akan semakin meneguhkan pesantren sebagai subkultur sebagaimana yang diungkapkan oleh Abdurrahman Wahid (Gus Dur). Meskipun pesantren tidak terdiri dari masyarakat semua budaya dan agama namun pesantren dapat menanamkan dasar-dasar dari nilai-nilai yang diusung oleh DUHAM.

Jika ilmu sosial yang ada selalu berelasi dengan kekuasaan yang ujungujungnya adalah modal, maka pesantren harus bisa melahirkan ilmu sosial ramah HAM yang lepas dari relasi-relasi kekuasaan. Sehingga dengan demikian pesantren perlu maelakukan revitalisasi subkultur pesantren sebagai bentuk mengawal kecenderungan pesantren yang kehilangan daya kreatifnya akibat dari melupakan tradisinya sendiri sebagai subkultur. Kencenderungan itu berupa menjiplak program-program pemerintahan berdasarkan pesanan penguasa.

Seharusnya dengan melakukan revitalisasi terhadap subkulturnya, pesantren secara mandiri dapat mengambil bagian dalam mengawal penegakkan role of low berupa: rule by the law (supremasi aturan hukum), equality before the law (kesamaan kedudukan didepan hukum), human rights protection (perlindungan hak asasi). Tentunya bukan sebagai unsur yang berada pada lingkaran penegak hukum tapi sebagai subkultur yang melahirkan ilmu sosial yang mengarah pada penegakan hukum. Dengan demikian daya kritis dan kemandirian pesantren bisa terus mewarnai penegakan HAM.

Dalam upaya mendorong kreatifitasnya, pesantren menjadikan fiqh sosial sebagai manhaj dan menjadi world view berbagai macam persoalan HAM di masyarakat, dengan menggunakan pendekatan ijtihad, maqosid syariah, dan maslahah mursalah. Sehingga lahirlah teori-teori sosial yang ramah HAM. 
Upaya-upaya diatas diharapkan ke depan dapat menguatkan peran dan kontribusi pesantren dalam menjaga ukhuwah islamiyah, ukhuwah wathoniyah, dan ukhuwah basyariyah yang dapat mengokohkan perdamaian yang berkeadilan bagi sesama umat Islam, sesama bangsa Indonesia dan sesama manusia diseluruh dunia.

\section{PENUTUP}

Seperti telah disinggung di depan, democratic governance sebagai remedi untuk negara-negara yang berada pada keadaan kritis memiliki beberapa keterbatasan yang harus bisa dengan tepat disiasati. Sejumlah keterbatasan itu adalah , pertama, bersama munculnya issues dan kondisi transisi yanq lain, konsep democratic governance akan mendapat perlawanan karena dirasakan sebagai tekanan dan bukan karena kebutuhan. Artinya, secara psikis democratic governance harus sengaja dibentuk sebagai suatu prasyarat atau usaha memenuhi standar formal dalam Percaturan internasional dan bukan karena sebuah keyakinan murni atas nilai dan manfaatnya. Namun demikian, hal ini dirasa lebih baik mengingat tanpa adanya "tekanan" semacam itu, perwujudan democratic governance akan dilakukan sambil lalu atau cenderung diabaikan.

Kedua, perlawanan terhadap democratic governance juga berpeluang terjadi bila ruang cakupannya berubah atau mengalami pergeseran. HAM yang sempat menjadi prioritas, sebagai contoh, tergeser oleh issue terorisme ketika terjadi sejumlah tindakan teror yang menimpa Amerika Serikat dan Australia. Dengan kata lain, pembenahan masalah HAM untuk menuju tercapainya democratic governance harus diberi tambahan beban, atau sebaliknya justru dikesampingkan dulu, dengan issues lain yang lebih dekat dengan kepentingan negara donor pemberi syarat democitic governance.

Ketiga, jika HAM dipandang memiliki karakter universal dan internasional, good goaernance mungkin belum sampai kepada pandangan 
sebagai nilai yang universal. Artinya, democratic governance yang ditumpukan pada tiga hal dalam persyaratan hubungan donor-resipien tidak sepenuhnya akan bisa diikuti karena usaha memenuhi Persyaratan di ruang-ruang lainnya tidak memiliki kecepatan yang sama dalam perwujudannya. Indonesia dalam hal ini masih dan perlu terus mencari eksistensi democratic governance-nya karena tiga ruang di dalamnya pun masih memerlukan pembenahan. Hal lain yang layak dicermati dalam terpenuhinya persyaratan itu adalah tarik menarik antara kondisi nyata (yang bisa dirasakan masyarakat) dan klaim keberhasilan (yang cenderung dikedepankan penguasa).

Keempat, copy program dari penerapan good governance dari satu negara ke negara yang lain kemungkinan justru menghasilkan pemujaan terhadap program itu, tanpa diikuti pemahaman untuk menyerap dan menerapkan substansinya di setiap tingkat pemerintahan. Sejumlah variabel tentunya harus dicermati agar PeneraPan Program yang "diimpor" itu dapat diterapkan secara tepat tanPa mengingkarinya bila memang pantas dan harus diterapkan. Sosialisasi terhadap program yang harus diterapkan, dan variabelvariabel tempatan mutlak dilakukan agar democratic governance yang ditargetkan memperoleh penerimaan yang hakiki.

Kelima, koverasi media massa tidak akan banyak membantu persebaran dan penerimaan good Governance, demokrasi, HAM dan hingga ke democratic governance karena agenda media dan agenda publik cenderung untuk tidak terlalu memperhatikannya. Persoalan riil di dalarn masyarakat rnenyebabkan partisipasi masyarakat dan partisipasi media untuk membantu tercapainya democratic goaernance menempati posisi kesekian, setelah sejumlah kebutuhan mendasar di dalam masyarakat terpenuhi. Arti lebih jauh lagi, partisipasi media dalam kaitannya dengan uPaya mencaPai democratic governances tetap mengalami kesulitan dalam merubah audiens pasif menjadi warganegara yang aktif. 


\section{REFERENSI}

Ali, Zainudin, Prof. Dr. M.A. (2006). Sosiologi Hukum. Jakarta : Sinar Grafika.

Alston, Philip. (1992).'The Commission on Human Right.' Dalam Philip Alston' (ed.). The United Nations and Human Rights. Oxford: Clarendon Press, PP' 126-210.Amnesty International.(1998). Amnesty International Report 1998: Australia. Archived at: http://www.amnesty.org/ailib/aireport/ar98/asa12.htm

Amnesty Intemational. (1994). Power and Impunity: Human Rights under the New order. Amnesty International USA. New York.

Andre Sudjatmoko (1999), Perlindungan HAM dalam hukum HAM dan Hukum Humaniter Internasional, Pusat Studi Hukum Humaniter, Fakultas Hukum Trisakti, Jakarta.

Aspinall, Ed. (1998). 'opposition and Elite Conflict in the Fall of soeharto.' Dalam Geoffrey Forrester dan R.J. May (eds')' The Fall of soeharto.Bathurst; Crawford House Publishing. pp. 130-153.

Cranston, M. (1973). What Are Human Rights? New York: Basics Books.

Djarot, Eros \& Haas, Robert. 1998. Hak-Hak Asasi Manusia dan Manusia (Human rightsand The Media). Jakarta : Yayasan Obor Indonesia.

Ghofur, A. (2019). Dakwah Islam Di Era Milenial. Dakwatuna: Jurnal Dakwah dan Komunikasi Islam, 5(2), 136-149.

Idjehar, Muhammad Budairi (2003), HAM versus Kapitalisme, Yogyakarta: INSIST Press.

Lubis, Todung M. (1993). In Search of Human Right, Jakarta: GrameJia Pustaka Utama and SPES Foundation.

Mala, F. (2020). Mengkaji Tradisi Nabi Sebagai Paradigma Dakwah Yang Ramah. Dakwatuna: Jurnal Dakwah dan Komunikasi Islam, 6(01), 104-127. Rachman, R. F. (2019). Optimalisasi Media Digital Berbasis Kemaslahatan Umat dalam Program Pahlawan Ekonomi Surabaya. IQTISHODUNA: Jurnal Ekonomi Islam, 8, 273-292. 
Rachman, R. F. (2019). Pengembangan Industri Kreatif Berbasis Media Digital di Surabaya dalam Perspektif Islam. KOMUNITAS, 10(2), 157-176.

Rachman, R. F. (2020). Kebijakan Pendidikan Anak Berkebutuhan Khusus Di Surabaya Dalam Perspektif Islam. Bidayatuna: Jurnal Pendidikan Guru Mandrasah Ibtidaiyah, 3(01), 125-143.

Rachman, R.F. (2018). Dakwah Intraktif Kultural Emha Ainun Nadjib. Jurnal Spektrum Komunikasi, 6(2), 1-9.

Rizkianton, Anggit Rizkianto, Manajemen Strategi Organisasi Dakwah (Studi pada Pimpinan Daerah 'Aisyiyah Surabaya) (Tesis, UINSA Surabaya, 2018), 1.

Ropingi El Ishaq, Pengantar Ilmu Dakwah (Studi Komprehensif Dakwah dari Teori ke Praktek) (Malang: Madani, 2016), 11.

Tempo. Co (kamis, 26 Desember 2013 )

Ubaidillah, Ahmad dkk (2000), Demokrasi, HAM, dan Masyarakat Madani, Jakarta: ICCE UIN Syarif Hidayatullah. 